\title{
THE SHEMA AND EARLY CHRISTIANITY ${ }^{1}$
}

\author{
Kim Huat Tan
}

\begin{abstract}
Summary
If Christianity emerged from the matrix of Judaism, how it conducted a dialogue - if it did at all-with the Jewish confession of its unique faith and praxis is a most interesting question. This essay claims not only did this take place frequently, as evident in the deployment of the Shema in many NT passages, it was also a flashpoint of debate between the Church and the Synagogue in the first century. It became an impetus of early Christian theological development, principally in the understanding of the constitution of the eschatological community and the identity of Jesus Christ.
\end{abstract}

\section{Introduction}

The Shema ${ }^{2}$ is in Jewish thought the supreme affirmation of the unity of God and its recitation may be regarded as the acceptance of the yoke of the kingdom of heaven. ${ }^{3}$ This being the case, it will be highly fascinating to study how early Christianity responded to the Shema, whether in its dispute with the Synagogue or for its own doctrinal development. Needless to say, the results accrued from such a study will have great significance for our understanding of the character of early Christianity and its parting of the ways with Judaism.

In order to proceed, an assumption has to be made. Along with the majority of the scholars, I trace the practice of the twice-daily recitation of the Shema back to pre-70 Judaism although the rabbinic period

1 An earlier version of this essay was given as 2006 Tyndale New Testament Lecture. I am grateful for the invitation to give the lecture and for all the comments made on that occasion.

2 In today's Jewish liturgy, it comprises three paragraphs: Deut. 6.4-9; 11.13-21 and Num. 15.37-41. The name is derived from the first word of Deut. 6.4.

3 L. Jacobs, 'Shema, Reading of', EncJud, 14.1372. 
certainly ensured that this practice became entrenched and widespread. ${ }^{4}$ Such an assumption may indeed be called into question in the light of b.Berakhot $21 \mathrm{a}^{5}$ and the peculiar use of it by Justin Martyr in his dialogue with Trypho. ${ }^{6}$ Without discounting the significance of these data, I have none the less concluded in a previous essay why it is still valid to regard the twice-daily recitation of the Shema as having its roots in that period. ${ }^{7}$ I shall not rehearse the arguments here but shall simply base myself on the results established there.

Others have laboured and I have entered into their labours. Unfortunately, not very much has been done in this area, even though the importance of the Shema to Judaism is widely recognised. Nevertheless, two names stand out and they must be mentioned so as to set my essay in context: Jeremias and Gerhardsson.

Jeremias pointed out long ago that all the citations of Deuteronomy 6:5 in the Gospels (Matthew 22:37//Mark 12:30; Mark 12:33; Luke $10: 27)$ differed from each other and did not conform to either the Masoretic Text or the LXX. He lamented that, up until his time, this glaring problem had not been addressed by any commentator. ${ }^{8}$ To

4 The key text here is m.Berakhot 1.1-4. Cf. Jacobs, 'Shema', 1370; A. F. Segal, Two Powers in Heaven: Early Rabbinic Reports about Christianity and Gnosticism (Leiden: Brill, 1977): 139; and P. Foster, 'Why did Matthew Get the Shema Wrong? A Study of Matthew 22:37', JBL 122 (2003): 309-33.

5 The text reads: 'Rabbi Judah said: If a man is in doubt whether he has recited the Shema', he need not recite it again. If he is in doubt whether he has said "True and firm", or not, he should say it again. What is the reason?-The recital of the Shema' is ordained only by the Rabbis, the saying of "True and firm" is a Scriptural ordinance.'

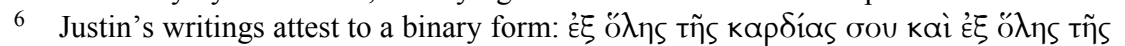
íxúos oov (Dial. 93.2; 93.3; 1 Apol. 16.6) but conjoined with the command to love neighbour. Justin probably derived this from the Gospel traditions because whenever Deut. 6 is referred to, it is for criticising Jewish religious accoutrements (Dial. 46.5). Furthermore, in his debate with Trypho over how Christology might be fitted into a monotheistic framework, there is no mention of the Shema (Dial. 37-42). Cf. R. F. Shendinger, 'A Note on the Variant Form of the Shema in the Writings of Justin Martyr', HTR 93 (2000): 161-63. For a concise but very informative treatment of the relationship between Justin and the Jesus traditions, see G. N. Stanton, 'Jesus Traditions and Gospels in Justin Martyr and Irenaeus', Jesus and Gospel (Cambridge: CUP, 2004): 92-109.

7 'Jesus and the Shema': to be published by Leiden-Brill in a volume that is provisionally known as Handbook to the Historical Jesus.

8 J. Jeremias, 'Daily Prayer in the Life of Jesus and the Primitive Church' in his The Prayers of Jesus (London: SCM, 1967): 66-81, esp. 80, which was given as a lecture during the eighth Semaine d'Études Liturgiques at the Institut de Théologie Orthodoxe Saint-Serge, Paris, in 1961. There was actually an exception. T. W. Manson took notice of it but confessed that it was a very complex textual problem, which he, 
make up for this neglect, he offered us the following historical reconstruction. Beginning from the premise that Jesus and his Jewish disciples must have recited the Shema twice a day, he proposed that the curious phenomenon in the Synoptic Gospels arose because the Greekspeaking church had replaced its recitation with that of the Lord's Prayer. This was done because it was believed the new had come and it must, of necessity, pour new content into old liturgical forms. ${ }^{9}$ This naturally contributed to the lack of precision over the wording of the Shema. ${ }^{10}$ If Jeremias is correct, the Shema element in the Gospel traditions may be regarded as a relic of a bygone era to early Christianity - at least the Gentile form of it. It would therefore have little bearing on its development.

Gerhardsson has spent a lifetime of studying the possible influence of the Shema on the Gospel traditions. His earliest foray into this topic in $1966^{11}$ concludes that the triadic pattern of the temptation story of Matthew 4:1-11 is based on the rabbinic interpretation of Deuteronomy $6: 5,{ }^{12}$ where the first temptation may be related to loving God with the heart, the second, the soul, and the third, the might (Mammon). Such a subtle but profound use of the Shema indicates for Gerhardsson that the temptation narrative was written as a coherent unit by a Pharisaic scribe, trained in the methods of rabbinic exegesis. ${ }^{13}$ This discovery led Gerhardsson subsequently to look for other Gospel passages that might provide evidence of their being influenced by the Shema at the deep structural level. His numerous efforts are now collected conveniently as a volume, which is entitled The Shema in the New Testament. ${ }^{14}$ Gerhardsson did not tackle the question raised by Jeremias regarding the anomalous form of the Gospels' citations of Deuteronomy 6:5. However, the implication of his conclusions is that, far from being a

unfortunately, was unable to solve. See his 'The Old Testament in the Teaching of Jesus', BJRL 34 (1951-52): 312-32, esp. 318.

9 One implication arising from this is that early Christianity sought to redefine itself over against its Jewish heritage and would therefore need accurate knowledge of the Shema. Jeremias did not seem to have noticed it.

10 Jeremias, 'Daily Prayer', 78, 81.

11 B. Gerhardsson, The Testing of God's Son (Matt 4.1-11 \& Par.) (Lund: Gleerup, 1966).

12 The key text in Gerhardsson's arsenal is m.Berakhot 9.5, although other rabbinic passages are utilised (Testing, 73-76).

13 Gerhardsson, Testing, 79-80.

14 B. Gerhardsson, The Shema in the New Testament (Lund: Novapress, 1996). 
relic, the Shema was a template for theological reflection and construction of Jesus traditions for early Christianity.

A relic or a template? They occupy positions at the opposite ends of the relevance spectrum. Even so, an answer may be obtained if we take a different approach. Instead of concentrating on the form or analysing deep structures, I propose we scrutinise the function instead, i.e. find out why the Shema is cited or alluded to in the relevant NT passages and what moves or statements the early Christian writers were trying to make. This will put us in a better position to answer questions about form and structure. However, this is a larger project, which I hope to complete one day. What I can offer now are some rather preliminary findings. Lest this small exercise become simply an analysis of early Christian responses to the Jewish doctrine of the oneness of God, tight controls must be imposed. ${ }^{15}$ We must use only those passages where the Shema is explicitly cited or referred to. After all, the Shema is more than just a locus classicus of Jewish monotheism. Indeed, the monotheistic belief forms its central component but it bears mentioning that there are two other components. These are the injunction to hear ${ }^{16}$ and the command to love Yahweh. This command may be regarded as the fundamental praxis of Israel and, consequently, has bearings on how covenantal identity is to be understood. ${ }^{17}$ In other words, treating the Shema as a Jewish credo or an important constituent of a community's liturgy has greater historical or theological payoff than treating it simply as a belief in monotheism in that it throws into bolder relief the issues at stake. When Christianity and Judaism laid claims to being the true religion of that one God, moves were made to appropriate resources from the same written Scriptures but with different conclusions. This inexorably leads to what Kenneth Cragg has so perceptively observed in another connection: 'language is quite literally where religions have to negotiate'. ${ }^{18}$ This becomes even more

15 It is quite common to find assumptions that the mention of the oneness of God must ipso facto be regarded as referring to the Shema.

16 The injunction, 'Hear, O Israel!' is sometimes used as shorthand for the Shema; see Genesis Rabbah 65.21 (on Gen. 27.22).

17 Cf. R. W. L. Moberly, 'Toward an Interpretation of the Shema', in Theological Exegesis, ed. C. Seitz and K. Greene-McCreight (Grand Rapids: Eerdmans, 1999): 124-44. See also, G. Keerankeri, The Love Commandment in Mark: An ExegeticoTheological Study of Mk 12,28-34 (Rome: Pontifical Biblical Institute, 2003): 22-43.

18 K. Cragg, Troubled by Truth: Life Studies in Inter-faith Concerns (Edinburgh: Pentland, 1992): 7. 
necessary when it concerns the language of something that has creedal status.

\section{The Shema and a Community's Boundaries}

It has frequently been pointed out that theology and praxis must also be understood sociologically, i.e. they create boundaries of a faith community. ${ }^{19}$ Using the insights of much recent work on Second Temple Judaism, we may then think of distinctive Jewish practices as creating a gulf between the Jews and the Gentiles, and these may thus be regarded as identity-forming. ${ }^{20}$ In this matter, the Jewish cult looms large. ${ }^{21}$ However, we have to bear in mind that identity is constituted not only negatively but also positively. In other words, it is not just about doing what others do not do but doing it whether others do so or not. ${ }^{22}$ This explains why Jews who, on the one hand, might seek to emphasise the distance between themselves and the Gentiles could nevertheless develop a concept of the righteous Gentile: those who are neither Jews nor followed Jewish practices but may none the less be described as not forgetting God. ${ }^{23}$

The Shema is often the focus of such complex conceptions of the relationship between Israel and the nations. The nations' gods are

19 One of the early advocates for the use of such a perspective for NT studies is G. Theissen. His first foray into this is his 'Wanderradikalismus: Literatursoziologische Aspekte der Überlieferung von Worten Jesu in Urchristentum', ZTK 70 (1973): 245 71. Some early English works utilising this perspective on the Gospels and Paul are P. F. Esler, Community and Gospel in Luke-Acts: The Social and Political Motivations of Lucan Theology (SNTSMS, 57; Cambridge: CUP, 1987) and F. B. Watson, Paul, Judaism and the Gentiles: A Sociological Approach (SNTSMS 56; Cambridge: CUP, 1986). The giants behind such a perspective are, of course, P. L. Berger and T. Luckmann, The Social Construction of Reality: A Treatise in the Sociology of Knowledge (Garden City: Doubleday, 1966). Cf. the follow-up work by P. L. Berger, The Social Reality of Religion (London: Faber and Faber, 1969).

20 See notably, on the new perspective on Paul, the essays by N. T. Wright, 'The Paul of History and the Apostle of Faith', TynBul 29 (1978): 61-88; and J. D. G. Dunn, 'The New Perspective on Paul', BJRL 65 (1983): 95-122.

21 Cf. N. T. Wright, The New Testament and the People of God (London: SPCK, 1992): 224-26, 233-35.

22 I owe this insight to an unpublished paper by F. B. Watson, which is entitled, 'Not the New Perspective', given at the British New Testament Conference in 2001

23 See t.Sanhedrin 13.2; b.Bava Batra 10b; t.Avodah Zarah. 8.4; cf. A.J. 20.34-48. For a good discussion of the concept, see T. L. Donaldson, Paul and the Gentiles: Remapping the Apostle's Convictional World (Minneapolis: Fortress, 1997): 65-69. Cf. also D. Novak, The Image of the Non-Jew in Judaism: An Historical and Constructive Study of the Noahide Laws (New York / Toronto: Edwin Mellen, 1983). 
nothing and Israel's God is the one and only potentate and creator. Not surprisingly, the renunciation of idolatry by Gentiles is sometimes reckoned as acceptance of the whole of Torah (b.Hullin 5a; b.Megillah 13a). But the logic may sometimes be taken to an extreme, where the concept of the Shema is also used to deny salvation to all outside Israel (Jubilees 15:25-32). All this sets the stage for our exploration of the use of the Shema in the discussion of boundaries and identity.

\subsection{The Synoptic Gospels}

We start with the pericope of Mark 12:28-34, which may be classified as a didactic story. ${ }^{24}$ This is the only NT passage that contains the full citation of the Shema, containing the injunction to hear, the affirmation of God's oneness and the command to love God. There are anomalies in the Markan adverbial modifiers to the command to love God but we shall treat them later.

The scribe's question which prompts Jesus' reply with the Shema

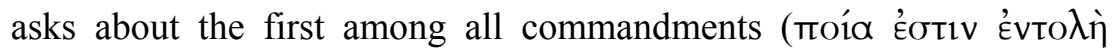

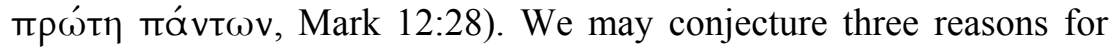
such a question. The first is that, given the plethora of laws and commandments, the enquirer wants to know whether they can be succinctly summed up. This leads to the second and it is that this summing up will reveal the essence of orthodoxy and orthopraxy. Consequently, one will then have a hermeneutic for interpreting Torah. Hence, whenever there is a conflict of laws, the enquirer will know which has priority. ${ }^{25}$ The third is that if the essence of one's faith and practice can be defined, the understanding of what constitutes membership in the covenant will then be clarified. ${ }^{26}$ At a time when there was great diversity in Judaism, ${ }^{27}$ such a question was most understandable. Indeed, Hillel was asked a similar question: whether he could teach the whole of Torah while the learner was standing on one

24 Cf. R. Bultmann, who classifies it as a scholastic dialogue, which offers an opportunity for an aspect of Jesus' teaching to be transmitted, The History of the Synoptic Tradition (rev. edn; Oxford: Blackwell, 1972): 54-55.

25 Note that the rabbis themselves discuss which commandments are 'heavy' and which are 'light'. The rabbis often used the word כלל כor a summarising principle. See b.Berakhot $63 \mathrm{a}$ and b.Makkot 24a.

26 Cf. Evans, Mark 8.21-16.20 (WBC, 34B; Nashville: Nelson, 2001): 263.

27 Cf. the essays in J. Neusner, W. S. Green and E. S. Frierichs, ed., Judaisms and Their Messiahs at the Turn of the Christian Era (Cambridge: CUP, 1987). 
leg. His reply was: 'Do not do to your neighbour what is hateful to you; this is the whole of Torah: the rest is commentary.' 28

Jesus' reply indicates that the Shema is the essence of the pluriform Torah and, therefore, provides the hermeneutic for a proper understanding of it. What is interesting is that Jesus goes on to speak of the second commandment, something which was not asked by the scribe. The reason for this is that the praxis of the Shema is inextricably linked with the praxis of loving one's neighbour. The conjoining of the love for God and the love for neighbour to form the key commands is certainly not the invention of the Church as there is ample evidence to show that many Jews in the Second Temple period thought the same (T. Iss. 5:2; 7:5; T. Dan. 5:3; Aristeas, Ep. 229; Philo, Virt. 95; Spec. $2: 63) .{ }^{29}$

What is highly fascinating and significant is that the scribe takes the cue from Jesus' reply to conclude that since the Shema sums up Torah, the cult is relativised (Mark 12:32-3). The logic at work here seems to be this: if there is one God, the key praxis of the people of God must be to love him, which involves also loving the neighbour. This being the case, the badge of covenantal identity cannot be supplied by the cult. Not surprisingly, the Markan setting of this discussion is the Temple (11:27). In some ways, this insight of the scribe is not unique, as it has already been anticipated in the OT, especially the Prophets (Jer. 6:20; 7:1-7, 21-8; Hos. 6:6; Amos 4:4; 5:4, 21-2; Mic. 6:6-8).

This insight elicits from Jesus the further reply that the scribe is not far from the kingdom of God (Mark 12:34). This is highly significant not just because the Gospel traditions are typically negative about the scribes. ${ }^{30}$ More importantly, the commendation of the scribe here makes reference to the kingdom of God, the key theme in Jesus' preaching. The point then is that the scribe, with his insightful answer, does not just show understanding of the implication of knowing what the essence of Torah is but also comes close to grasping the essence of

28 See b.Shabbat 31a. Cf. also Rabbi Akiba's statement in Sipra Leviticus § 200 (on Lev. 19.15-20).

29 Cf. D. C. Allison, 'Mark 12.28-31 and the Decalogue', in The Gospels and the Scriptures of Israel, ed. C. A. Evans and W. R. Stegner (JSNTSup, 104; Sheffield: Sheffield Academic, 1994): 270-78.

30 This is true even for Mark. The earlier chapters show them in conflict with Jesus $(2.6-7,16 ; 3.22 ; 7.1,5 ; 8.31 ; 10.33 ; 11.18 ; 11.27)$. For a treatment on Mark's attitude towards scribes, see É. Trocmé, The Formation of the Gospel according to Mark (London: SPCK, 1975): 94-99. 
Jesus' ministry. Perhaps we may flesh out the underlying theological currents in this manner. What is implied in Jesus' answer with the Shema is that he is harking back to the pristine period of Israel's faith before-according to the story of the OT-religion was institutionalised through the building of the Temple. When this is juxtaposed with Jesus' announcement of the dawn of the eschaton, we can then infer that for Jesus the concept of Endzeit = Urzeit often operates (cf. the pericope on divorce, Mark 10:2-12//Matt. 19:3-12). The Endzeit recaptures and fulfils the intentions of the Urzeit. The key point is that the kingdom of God, i.e. the Endzeit recapturing the Urzeit and demonstrating that what endures through time is the fundamental belief and praxis of Israel, is summed up in the Shema and expressed through the loving of one's neighbour. This is what it is meant when God is said to rule powerfully. ${ }^{31}$ Hence, Jesus' ministry does not lead to an abandonment of Jewish fundamentals but it does call into question the use of the cult as a badge of identity. Loyalty to the essence of Torah is not the same as loyalty to the cult.

We are now in a position to suggest an answer to the anomalies of form. The following table sets out the relevant data, including those from Matthew 22:37 and Luke 10:27.

Table 1: The modifiers and their order

\begin{tabular}{|c|c|c|c|c|c|c|}
\hline MT & LXX & LXX & Mark & Mark & Matt. & Luke \\
\hline & Rahlfs & Göttingen & $12: 30$ & $12: 33$ & $22: 37$ & $10: 27$ \\
\hline לִבָב & 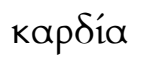 & 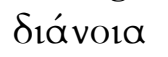 & 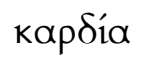 & 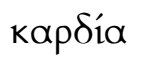 & 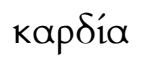 & кapdía \\
\hline נֶפֶּט & $\psi v x \dot{\eta}$ & uvxń & $\psi u X \bar{~}$ & oúveOtS & $\psi v x \dot{~}$ & 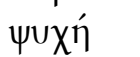 \\
\hline מִאיא & 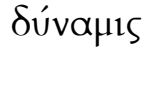 & 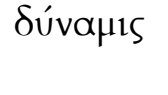 & $\begin{array}{l}\text { Siávoia } \\
\text { ioxús }\end{array}$ & ioxús & Siávola & $\begin{array}{l}\text { ioxús } \\
\text { Sióvora }\end{array}$ \\
\hline
\end{tabular}

Apart from Jeremias' proposal that the Markan anomalies indicate the unfamiliarity of the Evangelists or the early church with the Shema, ${ }^{32}$ the one frequent answer given in the scholarly literature is that the liturgical use of a passage does not necessarily lead to a fixity of its form. ${ }^{33}$ Consequently, Mark or the tradition he uses is not bound to the

31 On the notion of God's Kingdom as God's royal rule, see the extensive discussion in J. P. Meier, A Marginal Jew. Rethinking the Historical Jesus: Mentor, Message and Miracles (New York: Doubleday, 1994): 234-88.

32 Jeremias, 'Daily Prayer', 78, 81.

33 Cf. D. K. Falk, 'Jewish Prayer Literature and the Jerusalem Church in Acts', in The Book of Acts in its Palestinian Setting, ed. R. J. Bauckham (Grand Rapids: Eerdmans, 
vocabulary or order of the MT or LXX. ${ }^{34}$ This is indeed plausible but there may be something else operating here. First, it must be noted that Mark, or the tradition he receives, is familiar with the triadic form of the command to love God. This is attested in the scribe's reply (12:33). The presence of the tetradic form in 12:30 need not then indicate unfamiliarity with the Shema. In fact, the first three modifiers used by the Markan Jesus are all attested by the LXX. The fourth modifier, i $\sigma \chi \cup$ S, while not found in the LXX traditions, may none the less be

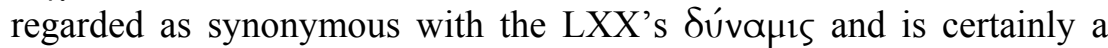
valid translation of the MT's מִאז (me'od). Of course, why are four modifiers used instead of three is still puzzling ${ }^{35}$ but the following observation may help. The second modifier in the scribe's citation of the Shema is unique in that oúveors stands in contrast with all the

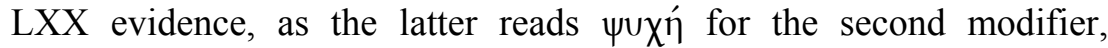
following the MT's בֶפֶ (nefesh). This unique word may be a clue to our puzzle. To begin with, oúveors may be regarded as synonymous with $\delta 1$ ávola, ${ }^{36}$ the word used for the first modifier in the Göttingen LXX, and in this sense, the scribe's reply does not venture into vocabulary outside the semantic territory provided by the different scriptural traditions (both LXX and MT). More importantly, this unique term actually comports well with the anomalous tetradic form of Jesus' citation of the Shema. In this citation, what stands out is the third modifier, $\delta ı \alpha$ vora, because it appears to be redundant since

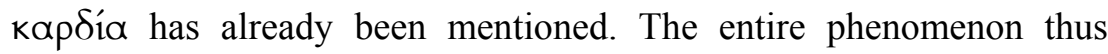
indicates that the noetic aspect of the discussion is emphasised. Indeed, the Markan pericope uses a word not attested anywhere else in the NT

1995): 276 n. 28. Mention may be made of the variation in the wording of the Lord's Prayer in Matthew, Luke and the Didache.

34 Cf. R. T. France, The Gospel of Mark: A Commentary on the Greek Text (NIGTC; Grand Rapids and Carlisle: Eerdmans and Paternoster, 2002): 479-80. R. H. Gundry

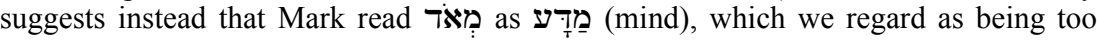
speculative. See his Mark: A Commentary on His Apology for the Cross (Grand Rapids: Eerdmans, 1993): 711.

35 Some scholars take this to be a result of Mark's hellenistic attempt at accentuating the totality of personal involvement in loving God. See J. Gnilka, Das Evangelium nach Markus, vol. 2 (Zürich: Benzinger, 1979) 164-65; and K. Kertelge, 'Das Doppelgebot der Liebe in Markusevangelium', in A cause de l'evangile: mélanges offerts à Dom Jacques Dupont, ed. F. Refoulé (Saint André: Cerf, 1985): 316.

36 However, oúveors is often used in the religio-ethical realm to signify the understanding which only God can give. See BDAG, 970. 
to characterise the scribe's answer in 12:34: vouvex $\tilde{\omega} \varsigma{ }^{37}$ This highlights again the noetic dimension. All this increases the probability

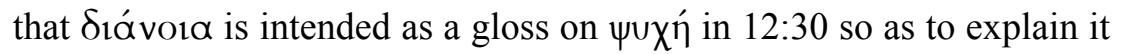
noetically. This in turn prepares the way for oúveots to be introduced and also to replace $\psi v \chi \chi^{\prime}$ and $\delta ı \alpha ́$ vor $\alpha$.

Thus, the whole pericope, with all its anomalies and uniqueness, emphasises understanding. This is not surprising, as the transcending of the cult by the Shema, which brings us close to the heart of Jesus' ministry, is not something transparent but requires profound understanding. ${ }^{38}$ If we are correct in so surmising, form is seen to be commandeered by intent and we may posit that behind this phenomenon lay a very creative mind.

The use of the Shema to relativise the cult, with the resultant effect of encouraging a rethinking of the boundaries of a community, is also found in another Synoptic pericope, the Parable of the Good Samaritan (Luke 10:25-37). I have treated this passage in a recent essay ${ }^{39}$ and I shall confine myself to summarising the results obtained there.

1. This passage is not derived from Mark 12:28-34 or the tradition which has given rise to it but comes from a separate tradition. ${ }^{40}$

2. The frame is to be used for understanding the parable's meaning. ${ }^{41}$

3. This meaning is about the Shema's being the identity marker of the covenant people and an authentic confession of it leads to life in the age to come. ${ }^{42}$

4. The parable is told in such a way as to elicit the answer that the neighbour the enquirer is asking about is actually the Samaritan. This comports with the notion that the Shema is the identity marker

37 LSJ, 1183: something done or expressed with understanding, being sensible or discreet. Cf. Aristotle, Rhetorica ad Alexandrum 30.7; Polybius I. 83.3.

38 Cf. a similar proposal by Gundry, Mark, 711: 'it [loving God with all you mind] may have the particular purpose of relating the command to love God to the intellectual activity that characterises a scribe such as Jesus' questioner'.

39 K. H. Tan, 'Community, Kingdom and Cross: Jesus' View of the Covenant', in The God of Covenant, ed. J. A. Grant and A. I. Wilson (Leicester: Apollos, 2005): 129-39.

40 Cf. T. W. Manson, The Sayings of Jesus: As Recorded in the Gospels according to St. Matthew and St. Luke (London: SCM, 1950): 259-60; and Evans, Mark 8.27-16.20, 262.

41 B. Gerhardsson, 'If We Do Not Cut the Parables out of Their Frames', NTS 37 (1991): 321-35, esp. 322-26.

42 Pace R. J. Bauckham, 'The Scrupulous Priest and the Good Samaritan: Jesus' Parabolic Interpretation of the Law of Moses', NTS 44 (1998): 475-89. 
of covenant membership. Consequently, what separates the Jew from the Samaritan, i.e. the cult, is invalid.

5. There is also an implicit widening of the concept of neighbour to embrace whoever in need.

All this coalesces with the themes identified in Mark 12:28-34 but with the difference that what is abstract in Mark 12:28-34 is made concrete in Luke 10:25-37: the Samaritan is named as member of the covenantal community.

\subsection{The Pauline Corpus}

In two instances we may see how Paul regards the Shema as axiomatic for his understanding of the identity of the new people of God, formed around the risen Messiah. When these passages are compared with those studied earlier, we observe a slight escalation in the relativising effect of the Shema. In Paul's conception, the Shema does not just relativise the cult, it also relativises Torah.

\section{a. Galatians 3:19-20}

Galatians 3:19-20 presents many puzzles to commentators because of the terse argument used. ${ }^{43}$ Terse as it may be, verse 20 is actually constructed with great care, evincing artistic balance: both clauses begin with ó $\delta$ '́, accompanied by the appropriate noun, with the verb ÉTılv ending them. In between the grammatical subject and the verb, the cardinal 'one' is used. ${ }^{44}$ It is probably best to regard Évós as being masculine, following Eís of the next clause. ${ }^{45}$ Thus, the syntactical

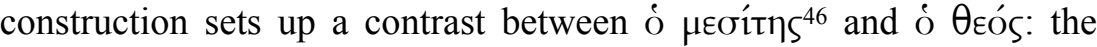

43 E. de W. Burton mentions that there are about 300 different interpretations for v. 20! See his A Critical and Exegetical Commentary on the Epistle to the Galatians (ICC; Edinburgh: T\&T Clark, 1921): 191. This datum came actually from G. A. Fricke, Das exegetische Problem Gal $3^{20}$ (Leipzig, 1879).

44 A structural analysis of this is hardly found in the major commentaries. Cf. J. L. Martyn, Galatians: A New Translation with Introduction and Commentary (AB, 33A; New York: Doubleday, 1997): 358, 365-70; B. Witherington III, Grace in Galatia: A Commentary on Paul's Letter to the Galatians (Grand Rapids: Eerdmans, 1998): $257-$ 59; R. N. Longenecker, Galatians (WBC, 41; Dallas: Word, 1990): 141-43. Limited attempts are found in H. D. Betz, Galatians: A Commentary on Paul's Letter to the Churches in Galatia (Hermeneia; Philadelphia: Fortress, 1979): 171; and Burton, Galatians, 191-92.

45 Burton, Galatians, 191.

46 Given the way the clauses are structured, Wright's suggestion that the article of in the first clause is pronominal, with $\mu \in \sigma i$ in serving as the complement, is syntactically improbable. See N. T. Wright, The Climax of the Covenant: Christ and Law in Pauline Theology (Edinburgh: T\&T Clark, 1991): 170. Furthermore, as Donaldson observes, if 
former is described as oúk Évós and the latter, with the simple Eís. Set in this way, the contrast may then be seen to be stark: the mediator is not of one while God is one. ${ }^{47}$

That said, it may also be observed that the complements in both clauses are in different cases, leading to a lack of perfect contrastive balance. This discrepancy is glaring given the fact that the clauses evince an attempt at artistic construction. For perfect contrastive balance to be achieved, both complements should either be in the nominative case or in the genitive case. Hence, the mediator may be described as 'not one' while God is 'one' but this makes no sense. Or God may be described as 'of one' to serve as a parallel to the mediator, who is described as 'not of one'. This will make good sense and if Paul wants perfect contrastive balance, we will expect him to write in such a manner. Furthermore, it will be congenial to the whole argument if a certain recent interpretation of this passage is to be adopted. According to this line of thought, the leitmotiv here concerns the oneness of God's Israel or family. The mediator's work and the Torah that was mediated through him do not bring about the one family. Instead, if Torah is strictly applied, it will create two families: a Jewish and a Gentile one. ${ }^{48}$ If this is the case, we should expect Paul to say that God is 'of one', i.e. is of the one family. But Paul actually writes 'God is one'. Clearly, this is a very cumbersome way for saying that God is behind the one family. These observations apply also against the common interpretation of positing a contrast of accessibility: the mediator's standing for two parties and the one God speaking directly. ${ }^{49}$

If we bracket out such hypotheses, the way is open for us to construe Paul's argumentation differently. In fact, the statement 'God is one' refers to the Shema ${ }^{50}$ and Paul is appealing to it for two reasons.

v. 20 is a simple assertion that Moses is not the agent of God's one promised family, the description of the former as mediator is wholly gratuitous (Donaldson, Paul, 87). Our manner of construing it regards ó Hєoítns as anaphoric. Cf. S. M. Baugh, 'Galatians 3.20 and the Covenant of Redemption', WTJ 66 (2004): 49-70, esp. 64-65.

47 Cf. Betz, Galatians, 171: mediator and God being mutually exclusive!

48 Cf. R. Bring, Commentary on Galatians (Philadephia: Muhlenberg, 1961): 148-54; and Wright, Climax, 169-70.

49 Cf. J. D. G. Dunn, The Epistle to the Galatians (BNTC; London: A\&C Black, 1993): 191; P. F. Esler, Galatians (London: Routledge, 1998): 199; Longenecker, Galatians, 142; and Witherington III, Grace in Galatia, 258.

50 See the analysis on different shorthand formulas used for the Shema in R. J. Bauckham, 'Biblical Theology and the Problems of Monotheism', in Out of Egypt: Biblical Theology and Biblical Interpretation, ed. M. Healy, K. Möller, R. Parry and C. Bartholomew (Carlisle and Grand Rapids: Paternoster and Zondervan, 2004): 219. 
First, there can be no greater appeal made. Secondly, it guarantees the integrity of God's plan and it therefore underwrites the existence of the new community. Paul's argumentative strategy then becomes clear: if this one God has made a promise to Abraham, which is realisable only by faith, then this one God will adopt the same modus operandi vis-àvis the new community that is established by Messiah Jesus. ${ }^{51}$ The Shema is thus used as the axiom to give guidance on the understanding of the relevance of Torah and the question of its genesis. ${ }^{52}$ God's plan has always been to effectuate the Abrahamic promise. The Torah is seen as part of that plan $^{53}$ but only with a preparatory role. A preparatory entity must not be used as a basis for determining how the eventual community is to be constituted. ${ }^{54}$ In other words, once the true nature of God is grasped, the true shape of God's plan and hence, the true function of Torah, will be understood. This true nature of God is something Jews confess each day in their recitation of the Shema.

When the intent of the statement 'God is one' is understood, we can decipher the meaning of 'the mediator is not of one'. ${ }^{55}$ The word 'of one' by itself is ambiguous and needs an accompanying noun to make its meaning clear, which, unfortunately, Paul does not supply. This being the case, 'of one' should take its hermeneutical cue from 'one' in the next clause. One possible result that arises from this is that we may posit $\theta \varepsilon o \tilde{u}$ (God) as the suppressed noun to accompany Évós (of one). This suppression allows Paul to suggest, but not speak, the unspeakable, i.e. connecting Torah to the angels, ${ }^{56}$ via the mediator, but not to God (v. 19), which serves the interest of protecting Paul from Jewish charges of antinomianism. ${ }^{57}$

51 Baugh sees the importance of the Shema in Paul's argument but suggests that Paul was really thinking of the intratrinitarian relationships! See his 'Galatians 3.20', 49-71.

52 Cf. Martyn, Galatians, 365, 370.

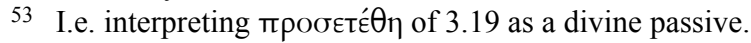

54 This is precisely what the verses following v. 20 seek to do.

55 For a similar line of argumentation, see B. W. Longenecker, The Triumph of Abraham's God: The Transformation of Identity in Galatians (Edinburgh: T\&T Clark, 1998): 55. Pace Burton, Galatians, 191, who regards the second clause as the minor premise to the first clause.

56 Most scholars regard the angelic involvement in the promulgation of Torah as being quite entrenched in Jewish tradition. Deut. 33.2 (LXX) is one key evidence. For a cautious approach to this matter, see F. B. Watson, Paul and the Hermeneutics of Faith (London: T\&T Clark International, 2004): 280.

57 Cf. the rather extreme statement of T. E. Van Spanje: 'Every exegesis which tries to ascribe a concrete connotation to $\mu \in \sigma i$ ins, and/or which makes a certain assumption

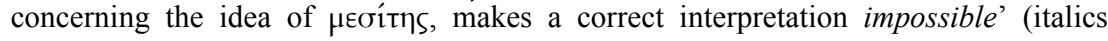


If verse 20 is construed as pitting the mediator-in this case, Moses $^{58}$ - against the one God, it can lead to a possible but frightening conclusion. This is eloquently described by Louis Martyn:

Taking the Galatians by the hand and coaxing them to draw the unstated conclusion, Paul leads them to the edge of an abyss and compels them to gaze down into its cavernous depth. There, without fully accepting itand without Paul's intending them fully to accept it — they have to look at the vision of a godless Law. ${ }^{59}$

Whatever one may think of Martyn's bold interpretation, he is certainly right to bring out the shocking nature of Paul's statement. Indeed, any interpretation of verse 20 that does not contain this shock effect makes the question of the next verse-which is answered straightaway with the emphatic $\mu \grave{\eta} \gamma^{\prime}$ v́volto-a non sequitur. ${ }^{60}$ That said, our proposed interpretation must be taken in context. In 3:21 Paul connects Torah to Promise, reclaiming it, as it were, from being a godless entity. Paul is thus aware that he is pushing his case too far if it is not properly qualified. ${ }^{61}$ Although qualification duly comes, the damage to the reputation of Torah has been done. But this is intentional on the part of Paul because he seeks to relativise Torah by appealing to the Shema. Believing in one God means that the Abrahamic Promise, which was divinely given before the advent of Torah, remains valid. The function of Torah then must take its cue from this Promise. In so doing Paul subtly opens up a new, important vantage point from which to view Torah. Torah should never be used to criticise the existence of the new community of God because it will then be pitted against the Abrahamic Promise, and this will be nothing less than speaking against the one God.

mine) in his Inconsistency in Paul: A Critique of the Work of Heikki Räisänen (WUNT 2, 110; Tübingen: Mohr Siebeck, 1999): 211-12. The quest for the referent of $\mu \in \sigma i$ ins is unavoidable if the contrast between God and mediator is intentionally set up by Paul in the context of the discussion of the validity of Torah!

58 S. K. Davis observes that the name 'Moses' is suppressed as part of Paul's compositional strategy to sideline him in favour of Abraham. See his The Antithesis of the Ages: Paul's Reconfiguration of Torah (CBQMS 33; Washington, DC: Catholic Biblical Association of America, 2002): 180-81.

59 Martyn, Galatians, 358. Cf. the remark of J. M. G. Barclay: '[Paul] almost denies the divine origin of the law'; Obeying the Truth: A Study of Paul's Ethics in Galatians (Edinburgh: T\&T Clark, 1988): 210. See also G. N. Stanton, 'The Law of Moses and the Law of Christ', in Paul and the Mosaic Law, ed. J. D. G. Dunn (Tübingen: Mohr Siebeck, 1996): 113.

60 Cf. Wright, Climax, 168.

61 Martyn is aware of this. See his Galatians, 368. 
Scholarly interpretations of verse 20 will naturally diverge because of the terse nature of the statements and the hidden premises. Even if we think Paul is arguing badly, what we must not miss is the clarity and significance of Paul's use of the Shema. According to him, Torah is being relativised by the Shema. Or to put it in a different way: election is being redefined by monotheism. The irony in all this, as it is perceptively observed by Wright, is that the Shema relativises that which it summarises. ${ }^{62}$ The upshot of the whole argumentation is that Torah is linked with the mediator, who is described as 'not of one', while the new community of faith is linked with the very fundamental confession of Israel: the Shema. This underwrites the existence of the new community and calls into question the use of Torah to prevent its establishment by faith in the Messiah.

\section{b. Romans 3:27-31}

Romans 3:27-31 contains a similar form of argumentation, identified earlier in the Galatians passage. There is no controversy over its interpretation and all that is needed for our purpose is to trace the argumentational development of this passage, especially verses 29-30.

Concluding the discussion which was started in 1:18, Paul proscribes Jewish boasting through Torah by arguing that since God is

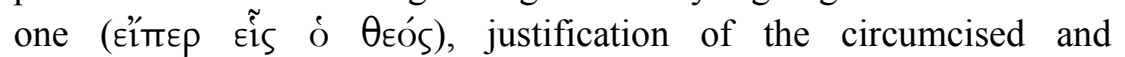
uncircumcised must come through only one means: faith. It is to be noted that the phrase عis ó $\theta$ eós is often a shorthand way of referring to the Shema. ${ }^{63}$ Paul is once again appealing to the fundamental confession of Israel to clinch his argument. The point made is aptly described by Mark Nanos: the proper understanding of the Shema forbids Gentiles from becoming Jews because to do otherwise will deny not just the oneness of God but also his election of Israel. ${ }^{64}$ Bauckham surmises that this form of argumentation may have been inspired by Zechariah 14:16-19, which envisages the universalising of the Shema. This implies for Bauckham that Israel's election is meant to be paradigmatic rather than exclusive. ${ }^{65}$

\footnotetext{
62 Wright, Climax, 170-71

63 Cf. Bauckham, 'Biblical Theology', 219.

64 M. D. Nanos, The Mystery of Romans: The Jewish Context of Paul's Letter (Minneapolis: Fortress, 1996): 184

65 Bauckham, 'Biblical Theology', 219-20.
} 
But what should not be missed is that Paul is not simply arguing that, because of the Shema, there can be only one people or one means of entry into that covenantal community. This would have been easily accepted by all, even Paul's opponents. Rather, as Donaldson observes, Paul is arguing for full (Gentile) membership into the covenantal community without the need for observance of Torah. This militates against usual Jewish thought on universalism, which operates with this idea: Gentiles will be accepted if they keep Torah precisely because there is only one God. ${ }^{66}$ The concept of the 'righteous Gentile' ${ }^{67}$ will not dovetail with Paul's argument either because these Gentiles were not treated by Jews as full members of the covenantal community.

The provocative nature ${ }^{68}$ of Paul's argument in Romans 1:18-3:31 then becomes clear. He is not saying that since there is only one God, both Jews and Gentiles may belong to the elect people of God. Instead, he is saying that since the Shema is true - an axiom accepted by the Jews - faith must be the only means for obtaining eschatological justification as this, and only this, will ensure the equality of Jews and Gentiles. Torah cannot therefore be the badge of identity for this eschatological community. In other words, he is not simply arguing for the inclusion of the Gentiles. Instead, he is arguing for the inclusion of all, both Jews and Gentiles, by faith and faith only. ${ }^{69}$ Dunn surmises that the reason for this may be that the one God is also the one Creator, and creation preceded the election of Israel, and thus, the one people must be both Jews and Gentiles. ${ }^{70}$ This seems incontrovertible but if the question is asked why it must be by faith and not something else, the usual answer is that faith is the response of creaturely dependence. ${ }^{71}$ Following this line of thought, the Pauline use of the Shema here may then be regarded as an appeal to the concept of the

66 Donaldson, Paul, 84-86.

67 Cf. $t$.Sanhedrin 13.2. Cf. Donaldson, Paul, 65-69. See also J. A. Ziesler, Paul's Letter to the Romans (London: SCM, 1989): 118.

68 E. Käsemann describes Paul's argument as 'in unerhörter Kühnheit'! See his An die Römer (Tübingen: Mohr, 1974): 96.

69 Cf. H. Moxnes, Theology in Conflict: Studies in Paul's Understanding of God in Romans (NovTsup, 53; Leiden: Brill, 1980): 223-24.

70 J. D. G. Dunn, Romans 1-8 (WBC, 38A; Dallas: Word, 1988): 189. Cf. N. A. Dahl, 'The One God of Jews and Gentiles (Romans 3.29-30)', Studies in Paul: Theology for Early Christian Mission (Minneapolis: Augsburg Fortress, 1977): 191.

71 Dunn, Romans 1-8, 193. Cf. also N. T. Wright, 'The Letter to the Romans', The New Interpreter's Bible, Vol. X, ed. L. E. Keck et al. (Nashville: Abingdon, 2002): 482. 
one Creator, which was already sounded in Romans 1 . Be that as it may, what Paul actually does next is to appeal not to creation but to salvation history in Romans 4. Paul argues that faith is already presupposed in the story of Abraham's election. Thus, the Shema is used not just to point to the one Creator but also to the one Lord and Architect of salvation history, who calls his one people into existence, using one paradigm. ${ }^{72}$ Significantly, a similar pattern is also found in Galatians 3:15-20. Abraham's election and the divine promise made to him was a result of faith, and the concept of the Shema means that this modus operandi is the definitive one. Hence, Torah is displaced from its pre-eminent position of the badge of covenantal identity. In both instances, Paul uses a fundamental belief that all Jews will agree to draw a fundamental conclusion that most Jews will disagree. ${ }^{73}$

\subsection{The Letter of James}

The Synoptic evidence dovetails with the Pauline in that the Shema in both traditions is used to discuss and redefine the boundaries of the covenantal community. In this redefinition, Jewish exclusivity is criticised, leading to an enlargement of the boundaries. The Synoptic evidence tells us that the Shema relativises the cult, and this means that the Samaritan may be included in the covenantal community. The Pauline evidence shows us that the Shema is deployed to relativise Torah and this leads to the conclusion that Gentiles are to be admitted to the covenant on equal terms with the Jews: not by the works of Torah but by faith. The central place of the Shema in all this cannot be overemphasised. But does James give us a different use of the Shema, with respect to the boundaries of the covenantal community?

To answer this fully, we will have to consider the debates about the relationship between Paul and James, especially their concepts of faith and works. Attempts have been made to show, how despite different emphases, the two do share some fundamentals. We do not have suggestions better than those offered by Bauckham ${ }^{74}$ but in keeping

72 This serves as a corrective to Dahl's idea that Paul owes this deployment of the monotheistic concept to Hellenistic influences. See his 'One God', 190-91.

73 Cf. Moxnes, Theology in Conflict, 41.

74 R. J. Bauckham, James: Wisdom of James, Disciple of Jesus the Sage (London: Routledge, 1999): 113-40. In it he concludes that Paul and James share much common ground, and the differences arise mainly from the fact that the occasion for James is different and that James is writing a paraenetic letter and thus, a proper comparison will be between James and the paraenetic sections of Paul's letters (139-40). 
with the purpose of this essay, we will simply make two observations about James's use of the Shema.

The first is that the Shema is not only referred to in James 2:19 but is very plausibly alluded to in different places. Verseput argues cogently that behind the language of 1:17 lies not the Greek concept of an immovable God but a berakah (benediction) that precedes the recitation of the Shema. It is combined with two other berakoth that surround the Shema to proclaim the themes of creation, election and redemption. ${ }^{75}$ James may then be regarded as using the central liturgical confession of the Jewish community to remind his Jewish readers in the Diaspora ${ }^{76}$ of the unswerving love of the covenant God. Furthermore, Bauckham suggests that 4:12 with the reference to the one lawgiver and the one judge may be an allusion to the Shema. He also suggests that the castigation of double-mindedness by James (1:8; $4: 8)$ harks back to the third element of the Shema, viz. loving God with all of one's heart, soul and strength. ${ }^{77}$ An interesting case for the influence of the Shema on the letter of James may then be made.

The second observation is of greater significance. It may be claimed that the use of the Shema in James 2:19 conforms to the pattern already seen in the Synoptic evidence. In 2:14-26, James is concerned to show that faith without works is dead. To clinch his case, it is expedient to use the most important test case. James cites the second element of the Shema, the belief in one God. ${ }^{78}$ The choice of this text is not arbitrary because the Shema represents the quintessence of the Jewish faith, which has apparently been taken over intact even by the early Jewish messianic communities. This quintessential belief is discussed in a context where works are not present and James's conclusion is that such an adherence to the Shema is not different from the demonic type: the demons also believe and tremble but remain demonic. What is of relevance here is that the works James refers to are not the distinctive Jewish practices but charitable works done for the neighbour (2:14-17). The concept of the neighbour plays a very important role in James. ${ }^{79}$ In

75 D. J. Verseput, 'James 1:17 and the Jewish Morning Prayers', NovT 39 (1997): 177-91.

76 Bauckham, James, 11-25.

77 Bauckham, James, 145.

78 Verseput, 'James 1.17', 188.

79 Cf. L. T. Johnson, 'The Use of Leviticus 19 in the Letter of James', JBL 101 (1982): 391-401. 
fact, the command to love the neighbour is described as a royal law

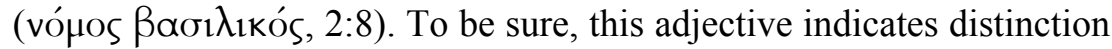
and pre-eminence. But it may also plausibly mean that the law of loving one's neighbour is connected with God's royal rule, i.e. the kingdom of God. ${ }^{80}$ This will then dovetail with the central emphasis of Mark 12:28-34. ${ }^{81}$

The upshot of all this is that James continues to regard the Shema highly. It is cited not because it is a piece of relic to be discarded but because it is the quintessential summary of faith. But James cites only the second element of the Shema and he believes that there is such a thing as an assent to it which borders on the demonic. The proper confession of the Shema then is to be seen in deeds for the neighbour, fulfilling the third element of the Shema. ${ }^{82}$ Notably, the remark $k \alpha \lambda \tilde{\omega} \varsigma$ $+\pi 01 \varepsilon \tilde{\imath} \tau \varepsilon$ ( $\pi 01 \varepsilon \tilde{i} \varsigma$ ) is used only twice in the letter: precisely at both instances of the citing of the command to love the neighbour and the Shema $(2: 8,19)$. Over against a demonic confession of the Shema stands the true confession which is embodied by loving deeds done for the neighbour. This then will be the true religion that God requires. Far from relativising the importance of the Shema, James actually exploits it to highlight the connection between the fundamental confession of one God and the love for neighbour. This is done in the interest of defining the true members of the community of God.

\section{The Shema and the Development of Christology}

It is not just for redefining the boundaries of the covenantal community that the Shema is deployed in early Christianity. We also have evidence that the inclusion of Jesus of Nazareth into the unique activity of the one God is also discussed and debated with the use of the Shema.

80 Cf. Bauckham, James, 142.

81 Some recent studies on the use of the Jesus traditions in James are W. H. Wachob, The Voice of Jesus in the Rhetoric of James (SNTSMS, 106; Cambridge: CUP, 2000); W. H. Wachob and L. T. Johnson, 'The Sayings of Jesus in the Letter of James', in Authenticating the Words of Jesus, ed. B. D. Chilton and C. A. Evans (Leiden: Brill, 2002): 431-50.

82 Cf. Bauckham, James, 147. 


\subsection{The Synoptic Evidence}

Recent scholarly discussion of 1 Corinthians 8:6 has highlighted this topic, which we will attend to later. But what is seldom noticed is that the Synoptic tradition presents quite a similar picture. ${ }^{83}$

\section{a. Mark 2:1-12}

This pericope has been classified as a controversy story, ${ }^{84}$ which, in this instance, concerns the forgiveness of sins. ${ }^{85}$ The placement of this story in Mark's narrative needs a closer study in order that its significance be fully understood.

By virtue of its being the very first controversy story, it takes on special significance. Furthermore, this comes straight after many passages that depict the triumph of Jesus over demons and diseases. The implication is that, although the Gospel is at work in wondrous ways, it nevertheless attracts controversy. And when it does, it is the type of controversy that is mentioned in Mark 2:1-12 that will be primary. It should also be noted that there is an apt connection between Jesus' proclamation and performance of the Gospel, and the concept of the forgiveness of sins. In the OT, the blessing of forgiveness is part and parcel of the restoration from exile (Isa. 43:25; 44:22). Restoration is in turn connected with Yahweh's return to reign in Zion, the reversal of fortunes and the 'Gospel', at least from the Isaianic standpoint (Isa. $52: 7 ; 61: 1-2){ }^{86}$

83 Bauckham suggests John 10.30 as a possible candidate for discussion in this section but he is aware the neuter "̌v is used instead of the masculine Ei s. Acknowledging this, he none the less thinks it is admissible because the switch in gender is a necessary adaptation of language. See his 'Biblical Theology', 227-29. For the sake of keeping to our tight controls, and to keep this essay within manageable proportions, discussion of this will not be carried out.

84 See the valuable discussion in R. A. Guelich, Mark 1-8.26 (WBC, 34A; Dallas: Word, 1989): 81-82. Cf. J. Marcus, Mark 1-8: A New Translation with Introduction and Commentary (AB, 27; New York: Doubleday, 2000): 213.

85 Cf. J. Kiilunen, Die Vollmacht im Widerstreit: Untersuchungen zum Werdegang von Mk 2,1-3,6 (Helsinki: Suomalainen Tiedeakatemia, 1985); 68-70 which is a better proposal than J. Dewey, Markan Public Debate: Literary Technique, Concentric Structure, and Theology in Mark 2:1-3:6 (Chico: Scholars, 1980): 109-16.

86 Cf. Stanton, 'Jesus and Gospel', Jesus and Gospel, 13-20, focussing mainly on Isa. 61.1-2; and N. T. Wright, Jesus and the Victory of God (Minneapolis: Fortress, 1996): 268-71. See also the magisterial treatment by P. Stuhlmacher, Das paulinische Evangelium (Göttingen: Vandenhoeck \& Ruprecht, 1968). Mark's use of Isaiah as an important template for developing his themes has been amply demonstrated. See R. Schneck, Isaiah in the Gospel of Mark I-VIII (BIBAL Dissertation Series 1; Vallejo: BIBAL, 1994); and R. E. Watts, Isaiah's New Exodus and Mark (WUNT 2, 88; Tübingen: Mohr Siebeck, 1997). 
Not only this, Jesus is also introduced as the Son of Man for the very first time. The Son of Man is the favourite self-designation of Jesus, explicated by different functions. ${ }^{87}$ Bearing in mind the form of this story, the implication then is that it is this particular claim of Jesus that causes controversy. Hence, this story apprises Mark's readers of what the primary conflict between Jesus and the religious authorities or between the early Christian communities and the synagogues will be. This conflict concerns not just the pre-eminent achievement of the Gospel (i.e. the forgiveness of sins) but also Jesus' understanding of his unique role as the Son of Man.

Mark 2:7 contains the objection of the scribes. As Joel Marcus observes, this objection is based on the Shema. ${ }^{88}$ We know this because the intent of the statement in Mark 2:7 is best expressed by using the adjective $\mu$ óvo to qualify $\theta \varepsilon$ có, instead of eís. Indeed, this is precisely what is done by Luke for Mark 2:7 (Luke 5:21). The use of the phrase Eis ó $\theta$ Eós cannot but mean that the Shema is exerting its influence on the text. This explains the charge of blasphemy: ${ }^{89}$ the Shema confesses one God and Jesus, by pronouncing forgiveness of sins for the paralytic, is judged to have encroached upon this exclusive confession. ${ }^{90}$

If this pericope is a reflection of Jewish-Christian debates, ${ }^{91}$ what may then be claimed is that the meaning of the Shema was one flashpoint. For the Synagogue, one God meant only one source of forgiveness. Early Christianity's reply was that the authority to forgive sins had been given to the Son of Man, who demonstrated it through healing. If this pericope is dominical, the point remains the same except that this time round the debate is between Jesus and the scribes.

Linking the notion of forgiveness with the action of healing, and subsuming these under the title of Son of Man, the pericope argues that

87 See the lucid treatment in Marcus, Mark 1-8, pp. 528-32.

88 J. Marcus, 'Authority to Forgive Sins upon the Earth: The Shema in the Gospel of Mark', in The Gospels and the Scriptures of Israel, ed. C. A. Evans and W. R. Stegner (JSNTSup, 104; Sheffield: Sheffield Academic, 1994): 196-211, esp. 197-98.

89 On the multi-faceted Jewish concept of blasphemy, see D. L. Bock, Blasphemy and Exaltation in Judaism and the Final Examination of Jesus (WUNT 2, 106; Tübingen: Mohr Siebeck, 1998).

90 See Midrash (Psalms) 17.3: 'No one can forgive transgressions except you (God)' but $\mathrm{cf}$. the fragmentary 4Q242 which may point in an opposite direction: a Jewish exorcist forgiving Nabonidus.

91 Cf. See R. Funk et al., The Five Gospels: The Search for the Authentic Words of Jesus (New York: Macmillan, 1993): 44, 90-91. 
Jesus has the authority to pronounce forgiveness. The implicit point may be that the Danielic Son of Man, acting as the vicegerent of God, performs the latter's tasks..$^{92}$ While this may be true, there is this other aspect that has to be noted. Jesus' claim brought forth the charge of blasphemy. This charge did not result in a retraction or clarifying of Jesus' claim. Nor did Mark add an explanatory note to refute it. The significance of this is seldom noted. What we have to remember is that the charge contains something of utmost importance to the Jew: the oneness of God confessed in the Shema. Not retracting or clarifying the claim is, in this instance, not the mark of a nice and soft-spoken gentleman but is tantamount to either being in tacit agreement with the charge or dismissing the significance of the Shema. If it were the latter, Jesus would certainly have put himself beyond the pale of Judaism. Furthermore, this does not square with the evidence provided by Mark 12:28-34, which shows Jesus' high regard for the Shema. The point then is that there is some truth to the charge, i.e. Jesus' action has implication for the understanding of the oneness of God confessed in the Shema. ${ }^{93}$

Some scholars have avoided this inexorable conclusion by arguing that Jesus was simply performing what priests would normally have done, i.e. to pronounce forgiveness for worshippers. Thus, Jesus can only be said to subvert the Temple or its authorities. ${ }^{94}$ It has also been argued that Jesus may be regarded as donning the mantle of the prophet and pronouncing the forgiveness of sins. ${ }^{95}$ If all this were the case, Mark would be describing unreasonable scribes because acting like a priest or prophet was not tantamount to calling into question the oneness of God. Furthermore, the Markan Jesus could have easily clarified but he did not. Hence, to accept these proposals, we will have to think of the incident as akin to ships passing in the night. The fact of the matter is that the way the pericope is set up implies the scribes have a valid point. Jesus did act in a way that implied he arrogated to himself an exclusive prerogative of God. ${ }^{96}$

92 Cf. France, Mark, 127-28; cf. Marcus, Mark 1-8, 531-32.

93 Cf. Marcus, Mark 1-8, 222.

94 Notably E. P. Sanders, Jesus and Judaism (London: SCM, 1985): 206-7, 273-74; and Wright, Victory of God, 268-74, 647.

95 Gundry, Mark, 117-18.

96 Cf. the conclusion of J. D. G. Dunn, 'Mark 2.1-3.6: A Bridge between Jesus and Paul on the Question of the Law' in his Jesus, Paul and the Law (London: SPCK, 
Therefore Mark, through this very first controversy story, presents what is a flashpoint between the Church and the Synagogue, ${ }^{97}$ and between Jesus and the religious authorities. It concerns the meaning of the Shema. One God means one source of forgiveness. Jesus does not contradict this syllogism but claims for himself the hallowed prerogative of this one God. Hence, the Shema is used to hint at the identity of Jesus: he truly performs what only God can perform and yet believes that the sanctity of the Shema is not compromised.

\section{b. Mark 10:17-22}

Arguably, the one other pericope in Mark that contains the phrase eis o $\theta$ Eós shows a similar theme. As was the case earlier, the intent of the statement in Mark 10:18 is best expressed by using the adjective Hóvo to qualify $\theta \varepsilon o$ s, instead of Ei $\tilde{\zeta}$, signifying yet again that the Shema is being appealed to. And in both instances, the Shema is used in connection with the exclusive prerogatives of God: in one, it is the forgiveness of sins, and in the other, the virtue of goodness. Detailed argumentation is not possible here ${ }^{98}$ but it is instructtive to observe the dialogical development between Jesus and the rich young man.

He addresses Jesus as good teacher before asking the question about how the life of the age to come may be obtained. Jesus' answer points to the Shema and declares that it is only the one God who is good. Not only does this radicalise the common notion of goodness, ${ }^{99}$ it also sets the stage for Jesus' listing of the commandments. ${ }^{100}$ The young man answers that all these have been fulfilled. To this Jesus replies that there is one thing he still lacks and this is explicated as selling all for the poor and following him. This final statement contains three important points. First, by giving all away the young man will be practising the Shema because he will be putting God above his wealth. ${ }^{101}$

1990): 26-27, where the Christological force of 2.7 and 2.10 is acknowledged. See also, Keerankeri, Love Commandment, 98-99.

97 See Deut. Rab. 2.32-33; cf. Segal, Two Powers, passim.

98 For an indication of how scholars usually interpret this, see Gundry, Mark, 553; and Evans, Mark 8:27-16.20, 96

99 Cf. France, Mark, 402

100 The interesting point to note is that the Nash Papyrus contains early evidence that the Ten Commandments were linked to the Shema. See S. A. Cooke, Proceedings of the Society of Biblical Archaeology 25 (1903): 34-56. Cooke dates it to the second or first century AD. The majority of scholars since then have regarded it as being written in the second century BC. See W. F. Albright, 'A Biblical Fragment from the Maccabean Age: The Nash Papyrus', JBL 56 (1937): 145-76.

${ }^{101}$ Evans, 98 
Secondly, by the command to give all to the poor, Jesus is implying that the Shema must go together with the love for neighbour. ${ }^{102}$ Finally, the command to follow Jesus climaxes these requirements, ${ }^{103}$ i.e. following Jesus is what truly confessing the Shema and keeping the commandments really amount to. This climactic command needs to be construed in relation to the very first statement of Jesus' reply and it indicates that Jesus does not intend to distance himself from this one God because it is by following Jesus that the Shema is truly confessed. In fact, the first statement of Jesus is meant to prod the enquirer to reflect on whether Jesus, by being addressed as 'good', is to be put on a par with the one God, whose goodness Jesus has radicalised. Therefore Jesus' identity is explicated in this Markan pericope with the help of the Shema. ${ }^{104}$ That which is used to speak exclusively of the one and only God is deployed to speak of the identity of Jesus of Nazareth.

\subsection{The Pauline Corpus}

That Paul was referring to the Shema in 1 Corinthians 8:6 has been amply demonstrated and discussed by many scholars. ${ }^{105}$ It will suffice for our purpose simply to summarise these results and add an observation or two of our own. The results adduced by these scholars are:

1. Paul uses Jewish monotheism as his main doctrinal framework in addressing the question of whether it is permissible to eat food that has been offered to idols. The Shema is alluded to as early as verse 3, where 'loving God' is emphasised. ${ }^{106}$

2. Paul in referring to the Shema bifurcates it, with the result that $\theta \varepsilon$ ós is used of the Father and kúpios of Jesus Christ. ${ }^{107}$ Such bifurcation is unprecedented.

3. Bifurcating the Shema implies that Paul is serious about adhering to Jewish monotheism ${ }^{108}$ but redefines it to include Jesus Christ. This may be known as the Christological redefinition of the Shema. ${ }^{109}$

\footnotetext{
102 Evans, 98

103 Evans, 99

104 Cf. Keerankeri, Love Commandment, 99-101.

105 J. D. G. Dunn, Christology in the Making: A New Testament Inquiry in the Origins of the Doctrine of the Incarnation (London: SCM, ${ }^{2} 1989$ ): 180; Wright, Climax, 12036; Bauckham, 'Biblical Theology', 220-26; A. C. Thiselton, The First Epistle to the Corinthians (Grand Rapids: Eerdmans, 2000): 636-38.

106 Wright, Climax, 127; Bauckham, 'Biblical Theology', 223.

107 Dunn, Christology, 180.

108 Bauckham, 'Biblical Theology', 224.
} 
4. Although the Shema is redefined, Jesus' identity is also clarified in that process. The variation in the use of the prepositions implies the inclusion of Jesus into the creative activity of the one God. ${ }^{110}$

It is to be noted that all this is done in the interest of introducing Jesus into a discussion that concerns monotheism and idolatry. The implication is that the one God of the Shema is known through Jesus, who died for the Corinthian community. This transforms the meaning of monotheism, as it does not just speak about the one God who knows them (8:3), but also the one Lord who has died for them (8:11). This dying act constituted the community of the Messiah. Thus, Paul urges the Corinthians to consider loving the weaker brother since this is how the one God has acted to bring about the existence of the community. This will then imply that the matter of idol food cannot be settled by merely appealing to knowledge. Love must also enter the equation. ${ }^{111}$ Such is the meaning of the Christologically-modified Shema.

What may be observed further is that since the Corinthian Church was predominantly Gentile, Paul's bifurcation of the Shema to include Christ implies that Gentile Christians were familiar with the Shema. The Shema then becomes not just Paul's debating strategy with the Jews but also a basic message to his Gentile converts. ${ }^{112}$ While redefining the most fundamental confession of Israel would have been nothing short of being revolutionary from the perspective of Paul's Jewish contemporaries, this actually provides Paul with the most potent and perspicuous tool for teaching the true identity of the one God and the one elect community, i.e. via an inclusion of Jesus into the hallowed confession and a proffering of an ethic that is shaped by the death of the one who is now included into that confession.

\section{Conclusion}

A relic or a template? A cluster of important passages stemming from the Synoptic, Pauline and Jacobean traditions refer to the Shema. By focussing on the function and not on the form or structure of these passages, we can conclude that the Shema was certainly not a relic to

109 Wright, Climax, 129.

110 Bauckham, 'Biblical Theology', 225-26; cf. N. Richardson, Paul's Language about God (JSNTSup, 99; Sheffield: Sheffield Academic, 1995): 296-304.

111 Cf. the line of argumentation by Wright, Climax, 131-33.

112 As observed by Donaldson, Paul, 87-88. 
early Christian communities. In fact, the evidence points to its being a flashpoint of debate and controversy between the Church and the Synagogue. Both communities were claiming to be the true confessors of the Shema. This will inexorably mean that it was also a template for doctrinal development for early Christianity and we have evidence for this in two key areas: the inclusion of Jesus into the identity of the one God and the redefining of the boundaries of the community, which involved relativising not just the cult but also Torah. The irony in this is twofold: that which marks out Israel's God is used to inform early Christian faith of the identity of Jesus of Nazareth, and that which sums up Torah is also that which is used to relativise it.

The early Christian use of the Shema would have thus been puzzling to the Jews, as it would come across as something familiar and yet unfamiliar. This is so because the early Christians used what all Jews would accept to reach conclusions most Jews would not. However, they would have argued - if Paul's evidence is anything to go by - that this was not done arbitrarily. In fact, they appealed to both the concept of God as the universal Lord and Creator, and the Abrahamic stories found in Scripture. In this sense, the early Christian use of the Shema was also an appeal to the concept of the one Lord and Architect of salvation history, but modified in a Christological way.

Perhaps all this amounts to bringing the new and eschatologically significant out of the old and familiar. But the old and familiar are still important since the new is often about how the old may be understood and taken significantly forward. In this respect, making recourse to the past (and old) is also the attempt of the present (and new) to seek anchorage in an otherwise uncertain hermeneutical sea, and in this sense, to understand itself much more clearly. As K. Hodgson and S. Radstone observe:

But to contest the past is also ... to pose questions about the present, and what the past means in the present. Our understanding of the past has strategic political and ethical consequences. Contests over the meaning of the past are also contests over the meaning of the present and over ways of taking the past forward. ${ }^{113}$

113 Cf. K. Hodgkin and S. Radstone, 'Introduction: Contested Pasts' in Contested Pasts: The Politics of Memory, ed. K. Hodgkin and S. Radstone (London and New York: Routledge, 2003): 1-21, esp. 1. 